\title{
Structural and spatial patterns of Isoberlinia species in a disturbed community forest (Benin, West Africa)
}

\author{
Cedric A. GOUSSANOU ${ }^{*}$, Brice A. TENTE ${ }^{2}$, Gaston AKOUEHOU ${ }^{3}$, Valere K. SALAKO ${ }^{4}$, Romain L. \\ GLELE-KAKAÏ ${ }^{4}$, Brice A. SINSIN ${ }^{1}$ \\ ${ }^{1}$ Laboratory of Applied Ecology, University of Abomey-Calavi, 01 BP 526, Cotonou, Benin. \\ ${ }^{2}$ Laboratoire de Biogéographie et d'Expertise Environnementale, University of Abomey-Calavi, 01 BP \\ 526, Cotonou, Benin. \\ ${ }^{3}$ Centre d'Etudes, de Recherche et de Formation Forestières, 06 BP 707 Cotonou, Benin. \\ ${ }^{4}$ Laboratoire de Biomathématiques et d'Estimation Forestières, 04 BP 1525, Cotonou, Benin. \\ *Corresponding author: cedricgoussanou@gmail.com
}

Received Date: 18.11.2016

Accepted Date: 10.04 .2017

\section{Abstract}

Aim of study: This study focused on the analysis of structural and spatial patterns of Isoberlinia spp stands according to topographic units.

Area of study: Data collection were carried out within the Zouzounkan forest reserve, located in Southern Benin.

Material and Methods: Square plots of 1 ha were considered for the forest inventory in which, geographical coordinates of Isoberlinia individuals were recorded. Ripley's K function was used to assess the spatial patterns of the species in the forest whereas dendrometric and ecological parameters was computed to analyze the structure of the species populations. Possible impact of topographic units of the forest reserve on dendrometric and spatial patterns of trees was assessed.

Main results: The results show that Isoberlinia spp. is more abundant on the hill side than on the top and down hills. Aggregative spatial distribution of trees was found across topographic units with more aggregation on the hill side. However beyond a radius of $8 \mathrm{~m}$ aggregation decreased. Furthermore, significant difference was noted on dendrometric patterns of Isoberlinia trees according to topographic unit.

Research highlights: Results obtained suggest that effective conservation strategy of Isoberlinia trees in Zouzoukan forest reserve should take into account topographical patterns.

Keywords: Structural and spatial pattern, Topography, Isoberlinia spp, Zouzounkan forest reserve, Benin Republic.

\section{Bozulmuş bir topluluk ormanındaki Isoberlinia türlerinin yapısal ve mekansal kalıpları (Benin, Batı Afrika)}

Özet

Çalışmanın amacı: Bu çalş̧̧ma topografik birimlere göre Isoberlinia spp duraklarının yapısal ve mekansal modellerinin analizine odaklanmıştır.

Çalışma alanı: Veri toplama işlemleri, Güney Benin'de bulunan Zouzounkan orman rezervi dahilinde gerçekleştirildi.

Materyal ve Yöntem: Isoberlinia bireylerinin coğrafik koordinatlarının bulunduğu orman envanteri için 1 ha'lık kare planlar düşünüldü. Ripley'nin K işlevi, ormandaki türlerin mekansal modellerini değerlendirirken, dendrometrik ve ekolojik parametreler, tür popülasyonlarının yapısını analiz etmek için hesaplandı. Orman rezervinin topografik birimlerinin dendrometrik ve mekansal ağaç desenlerine olası etkileri değerlendirildi.

Temel Sonuçlar: Sonuçlar, Isoberlinia spp. Tepe tarafinda tepeden ve aşağ tepeden çok toplam alan dağılımıyla daha fazladır. Bununla birlikte, 8 m'lik bir yarıçapın ötesinde agregasyon azalmıştır. Ayrıca, topoğrafik birime göre Isoberlinia ağaçlarının dendrometrik modelleri üzerinde önemli bir fark vardı.

Araştırma vurguları: Zouzoukan orman rezervindeki Isoberlinia ağaçlarının etkili koruma stratejisi, topografik kalıpları hesaba katmalidır.

Anahtar kelimeler: Yapisal ve mekansal model, Topografya, Isoberlinia spp, Zouzounkan orman rezervi, Benin Cumhuriyeti. 


\section{Introduction}

The conservation of woody species requires an understanding of driven factors of their distribution (Ruston, Ormerod, \& Kerby, 2004) which was one of issues in ecology and conservation for plant ecologists (Svenning et al., 2004; Law et al. 2009). Therefore, spatial analysis patterns of trees was an important tool to understand the arrangement of the system (LinaresPalomino, 2005) and had become a widely used approach in ecological research (Liebhold \& Gurevitch, 2002; Revilla \& Palomares, 2002; Liang \& Dong, 2004; Wiegand \& Moloney, 2004). In tropical forest, many studies have shown the dependence of plant distribution to local environment especially on edaphic factors, altitude, latitude and topography (Schemske 2002; Phillips et al., 2003; Lomolino, Sax, \& Brown, 2004; Svenning et al., 2004). Such information is helpful in gathering reliable data on the ecology of plant species for their efficient management.

Topographical patterns of forest were known to impact tree-species distribution (Oliveira-Filho, Vilela, Carvalho, \& Gavilanes, 1994; Tateno \& Takeda, 2003). According to Jones et al. (2008), topographic variation may produce structure at different scales depending on underlying geomorphology. In addition, Clark, Clark, and Read (1998) found a variation in tree species composition along topographical gradient. Abundances of many species also changed with topography which indicates that topography predicts the composition of tree species (Valencia et al., 2004; Lan, Hu, Cao, \& Zhu, 2011).

In Benin, some studies have been done to establish and analyse the link between distribution of species and their environmental conditions. Among them the relationship between vegetation and soil types (Awokou, Ganglo, Azontondé, Adjakidjè, \& De Foucault, 2009); the influence of habitat type on Tamarindus indica (Fandohan, Assogbadjo, Glèlè-Kakaï, Sinsin, \& Van Damme, 2010) and the distribution of Anogeissus leiocarpa according to the ground water (Guédou, 2005) were carried out. This study intend to assess the topographic effect on spatial distribution of Isoberlinia spp. within Zouzounkan forest reserve. Indeed, geomorphology of the Zouzounkan forest reserve is a tangle of hills mainly dominated by Isoberlinia spp. natural stands (Djègo, Gibigaye, Tente, \& Sinsin, 2012). Isoberlinia spp. was currently one of the most exploited species especially for its wood and this human pressure leading to some disturbance within the forest. Then, understanding relationship between topography and spatial pattern constitutes a relevant forward step in the description and analysis of the ecology of plant species. The study objective is the assessment of spatial pattern and structure of Isoberlinia spp. stand according to topographic units in the Zouzounkan forest reserve.

\section{Material and Method \\ Study area}

Data were collected within woodlands dominated by I. doka and I. tomentosa in the Zouzounkan forest located in the Zangnanado town, central region of the Republic of Benin, between $2^{\circ} 11^{\prime}-2^{\circ} 22^{\prime} \mathrm{N}$ and $7^{\circ} 20^{\prime}-7^{\circ} 33^{\prime}$ E (Figure 1). The Zouzounkan forest covers an area of about 29,492 ha composed of woodlands, savannas, fallows and crops (Agbahoungba, 2009). Other species most abundant in these woodlands were Parkia biglobosa, Prosopis africana and Anogeissus leiocarpa. In savannas, the most common species were Combretum nigricans, Detarium microcarpum, Gardenia erubescens and Gardenia ternifolia (Orthmann, 2005). Relief is a plateau with elevation ranged between 200 to $300 \mathrm{~m}$ (PBF-II, 2010).

There is a large occurrence of rocky outcrops in Zouzounkan forest reserve, however three types of soils can be recognized in the study area namely ferruginous, ferralitic and hydromorphic soils (Slansky, 1962). The study area is characterized by a bimodal rainfall regime from April to June. The mean temperature varies between $25^{\circ} \mathrm{C}$ and $31^{\circ} \mathrm{C}$ and the relative humidity ranges between $57 \%$ and $87 \%$. The population closed to the forest is composed of Fon, Mahi, Peulh and Yoruba socio-cultural groups (Agbahoungba, 2009; PBF-II, 2010). They interacted with the 
forest through their activities such as

agriculture, logging, and charcoal

production.

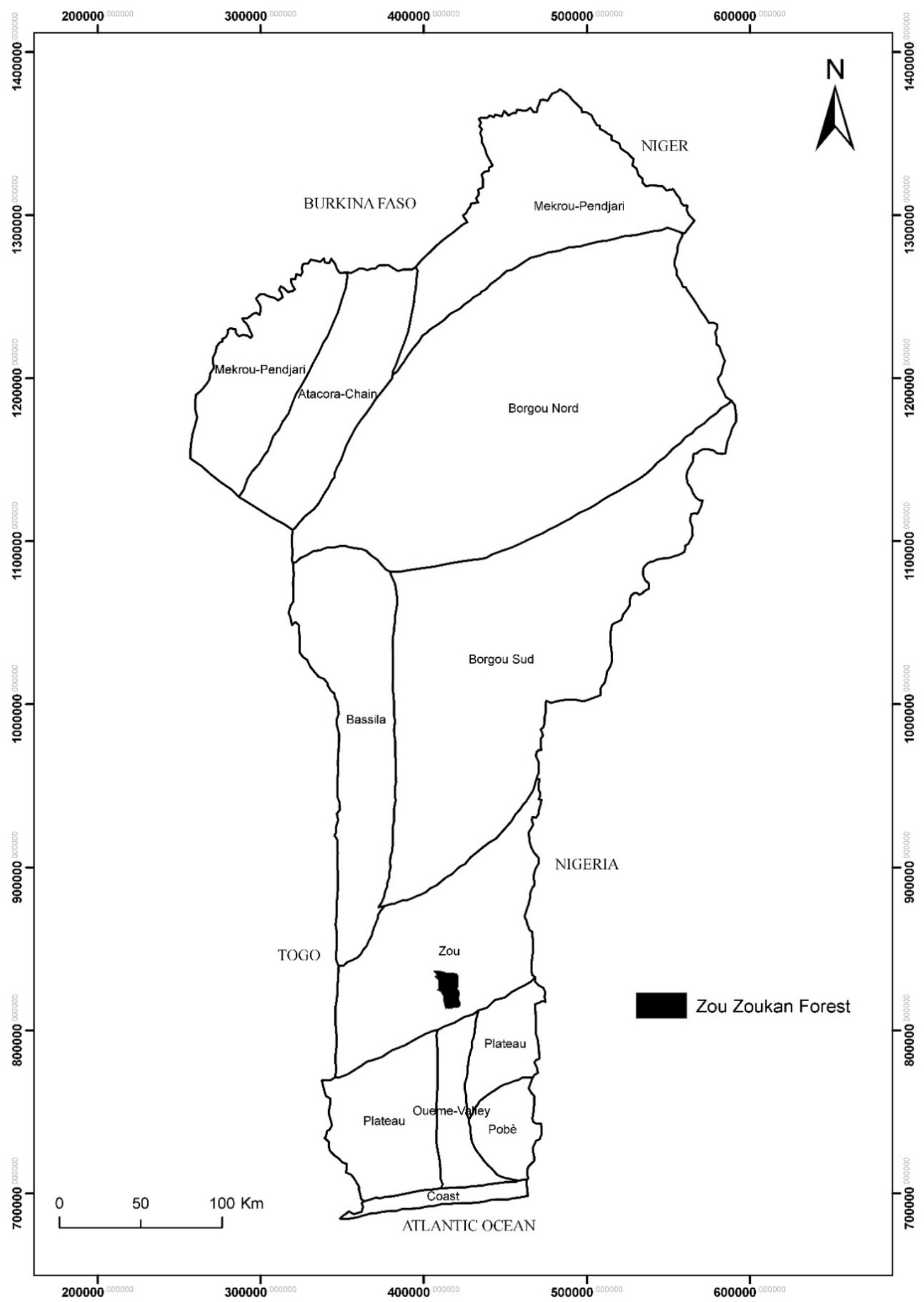

Figure 1. Location of study area 


\section{Sampling and data collection}

Six square plots of 1 ha were considered in homogeneous and non-disturbed habitats in the forest. All the plots have similar biophysical characteristics especially in terms of vegetation, elevation and slope. Two plots was set by topographical unit (top hill, hill side and downhill). The mapping process consisted of linking each tree with one of its neighbours by distance, azimuth and slope. Diameter at breast height (dbh) and total height were measured for each trees with diameter at breast height greater than or equal to $10 \mathrm{~cm}$. Each measured trees were labelled to avoid replications and omissions. In addition, data on crown shape, stem shape and health statement of measured trees were recorded. Three modalities of crown shape were considered namely "well developed", "fairly developed" and "little developed". Trees stem shape was considered as "straight", "leaning" or "twisted". Five modalities of health statement of trees ("good", "broken top", "rot", "wound" and "more than one defect") were considered.

\section{Data analysis}

Azimuth, slope and distance data were converted in $\mathrm{x}, \mathrm{y}$ coordinates for each tree with Arpent 1.3.d software (Lejeune, 2001). Spatial distribution of trees was displayed with R software. The "nndist" procedure of the package "Spatstat" was set to determine the observed minimum and maximum distance value to the nearest neighbour $(\mathrm{k}=$ 2). The Ripley's K(r) and the pair correlation g(r) functions were used to investigate the type of distribution shown by adult individuals of Isoberlinia spp. (Ripley, 1977; Goreaud, Courbeau, \& Collinet, 1999; Klimas, Kainer, \& Wadt, 2007; Djossa et al., 2008). The expected neighbours $\mathrm{K}(\mathrm{r})$ by (Ripley, 1977) and the linearized function L(r) proposed by Besag (1977) were used to simplify pattern interpretation of Isoberlinia spp. For each plot, species richness, Shannon's diversity index (H, in bits), Pielou's evenness (Eq), tree density, basal area of the stand $(G)$ and basal area contribution (Cs, in per cent) were computed. The mean and standard deviation of dendrometric parameters were computed for each topographic unit. As the data did not fulfil the assumptions (normality and homoscedasticity) of the analysis of variance test, the non-parametric test of KruskalWallis was performed at $5 \%$ confidence level with $\mathrm{R}$ software to compare the structural parameters between topographical units. The relative frequencies of Isoberlinia spp. trees found in each topographic unit according to different shapes of trees crown, different trees stem shape and trees health statement was also computed. To test the effect of topography on these three characteristics of Isoberlinia spp. trees (crown shape, stem shape and health statement), log-linear analysis (Agresti, 1990) was performed in each case on the frequencies of trees according to the modalities of the considered trait and the topographic unit.

\section{Results}

Ecological and dendrometric patterns of Isoberlinia spp. stands

The table 1 presents diversity indexes and dendrometric parameters according to topographic unit and for the whole stand. The ecological parameters of Isoberlinia stands in the forest varied according to the topographic unit (Table 1). Shannon diversity index (H) varied slightly, from 2.63 (hill side) to 2.72 bits (downhill). The same trend was observed for Pielou's evenness index which ranged from 0.58 (hill side) to 0.62 (downhill). In the same topographic unit, values of the mean diameter of $I$. doka were higher than the ones related to the whole topographic unit, while for I. tomentosa an opposite trend was observed. For the both species of Isoberlinia, the highest values were found on hill side. However, dendrometric values of $I$. doka were higher than the ones linked to $I$. tomentosa. Probabilities of the KruskalWallis test shown a significant difference among the topographic units based on the median height and tree-density of the stands. These values then revealed that the individuals of $I$. doka were more abundant and taller with large diameter than those of $I$. tomentosa. 
Table 1. Structural characteristics of Isoberlinia stands according to topographic units: mean, (m) coefficient of variation (Cv) and probability (P) of ANOVA.

\begin{tabular}{|c|c|c|c|c|c|c|c|}
\hline \multirow{2}{*}{ Parameters } & \multicolumn{2}{|c|}{ Top hill } & \multicolumn{2}{|c|}{ Hill side } & \multicolumn{2}{|c|}{ Downhill } & \multirow{2}{*}{$\mathrm{P}$} \\
\hline & Mean & $\mathrm{Cv}(\%)$ & Mean & $\mathrm{Cv}(\%)$ & Mean & $\mathrm{Cv}(\%)$ & \\
\hline \multicolumn{8}{|c|}{ Whole stands } \\
\hline Species richness (S) & 20 & - & 23 & - & 22 & - & - \\
\hline Shannon index (H, bits) & 2.69 & - & 2.63 & - & 2.72 & - & - \\
\hline Pielou eveness (Eq) & 0.62 & - & 0.58 & - & 0.61 & - & - \\
\hline Tree-density (stems/ha) & 175 & - & 259 & - & 224 & - & $<0.001$ \\
\hline Basal area (m²/ha ) & 7.11 & - & 12.17 & - & 9.60 & - & 0.61 \\
\hline Mean diameter $(\mathrm{cm})$ & 20.99 & 41.09 & 22.10 & 47.54 & 21.59 & 41.35 & 0.61 \\
\hline \multicolumn{8}{|c|}{ Isoberlinia doka } \\
\hline Mean diameter $(\mathrm{cm})$ & 24.84 & 32.00 & 25.62 & 31.51 & 24.40 & 33.34 & 0.64 \\
\hline Mean height (m) & 12.21 & 28.75 & 17.81 & 30.66 & 19.34 & 37.01 & $<0.001$ \\
\hline Basal area (m²/ha) & 4.26 & - & 8.27 & - & 4.37 & - & 0.64 \\
\hline $\begin{array}{l}\text { Basal area } \\
\text { contribution }\left(\mathrm{Cs}_{\mathrm{do}, \%}\right)\end{array}$ & 59.94 & - & 67.95 & - & 45.52 & - & - \\
\hline Tree-density (stems/ha) & 80 & - & 146 & - & 99 & - & $<0.001$ \\
\hline \multicolumn{8}{|c|}{ Isoberlinia tomentosa } \\
\hline Mean diameter $(\mathrm{cm})$ & 17.42 & 45.86 & 18.87 & 31.83 & - & - & 0.23 \\
\hline Mean height (m) & 7.08 & 54.37 & 11.33 & 35.25 & - & - & 0.01 \\
\hline Basal area $\left(\mathrm{m}^{2} / \mathrm{ha}\right)$ & 1.09 & - & 0.40 & - & - & - & 0.23 \\
\hline $\begin{array}{l}\text { Basal area } \\
\text { contribution }\left(\mathrm{Cs}_{\mathrm{to}, \%}\right)\end{array}$ & 15.34 & - & 3.27 & - & - & - & - \\
\hline Tree-density (stems/ha) & 38 & - & 13 & - & - & - & $<0.001$ \\
\hline
\end{tabular}

\section{Analysis of spatial distribution}

Aggregative distribution were found in all topographic units (Figure 2). The graph of $\mathrm{L}(\mathrm{r})-\mathrm{r}$ function of Isoberlinia spp. trees gave a random trend of distribution from 0 to $2 \mathrm{~m}$ and aggregative above $10 \mathrm{~m}$ with the peak respectively at around $8 \mathrm{~m}, 12 \mathrm{~m}$ and $7 \mathrm{~m}$ for top hill, hill side and downhill.

Impact of the topography of forest site on Isoberlinia spp. trees shape

Results of log-linear analyses performed to test the effect of topographic units on the distribution of Isoberlinia spp. according to its trees traits ("shape of trees crown", "trees stem shape" and "trees health statement") (Table 2) revealed significant effect $(\mathrm{P}<$ 0.05 ) of the topography of Zouzounkan forest. Significant difference $(P<0.05)$ was also noted between the numbers of Isoberlinia spp. trees according to the type of the shape of trees crown. 

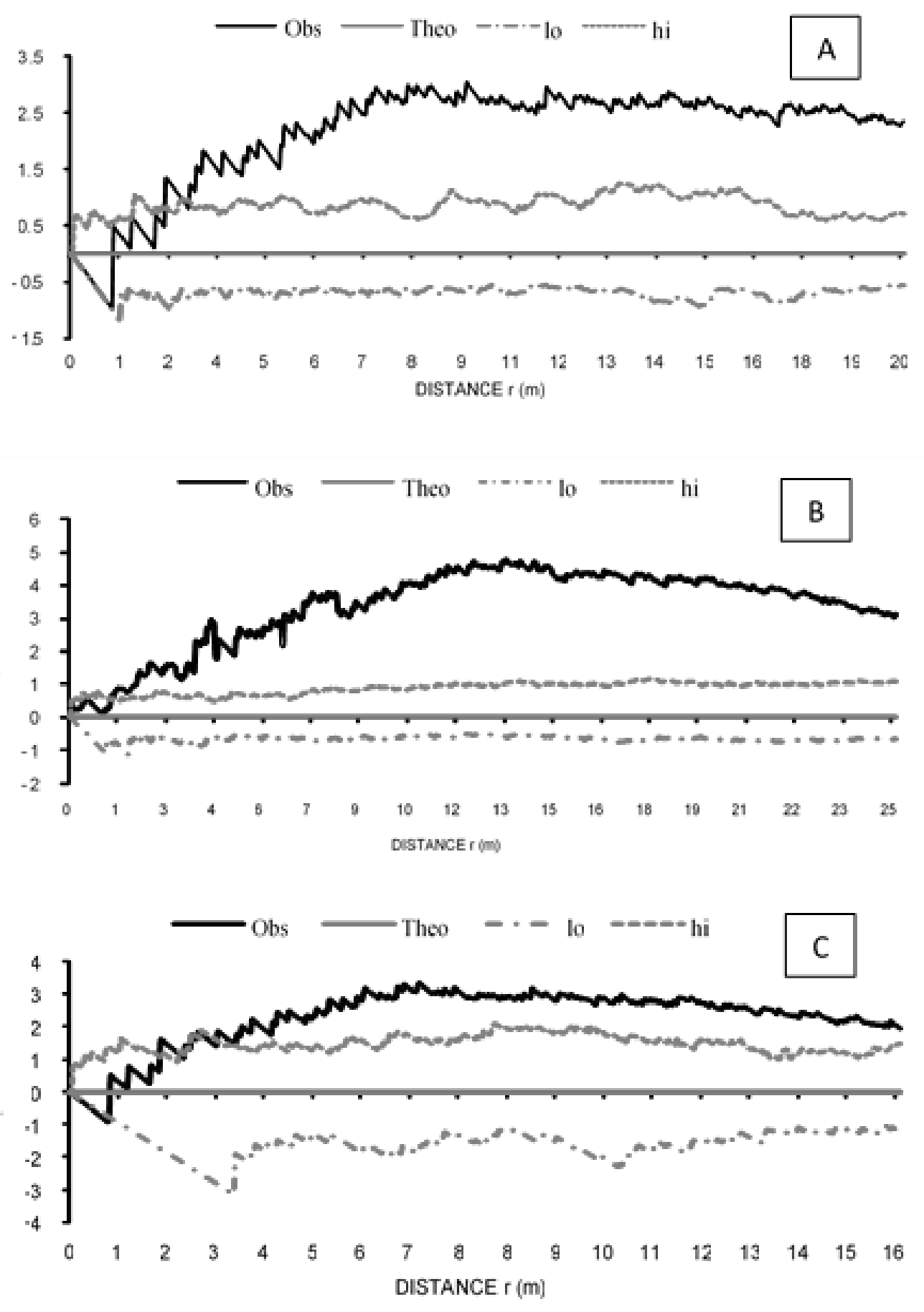

Figure 2. Spatial pattern of Isoberlinia spp. on top hill (A), hill side (B) and downhill (C) 
Table 2. Effect of topographic units on Isoberlinia spp. population distribution: results of log linear analysis

\begin{tabular}{lccc}
\hline Source of variation & DF & Chi-Square & P \\
\cline { 2 - 4 } & & Crown shape & 0.05 \\
\hline Topography & 2 & 5.97 & 0.00 \\
Shape of trees crown & 2 & 77.70 & 0.20 \\
Topography * Crown shape & 4 & 5.92 & 0.00 \\
\hline & & Stem shape & 0.00 \\
Topography & 2 & 11.14 & 0.00 \\
Stem shape & 2 & 61.81 & 0.00 \\
Topography * Stem shape & 4 & 20.84 & 0.00 \\
& & Health statement & 0.00 \\
\hline Topography & 2 & 13.17 & \\
Health statement & 4 & 202.73 & 18.81 \\
Topography * Health statement & 5 & &
\end{tabular}

Legend: $\mathrm{DF}=$ degree of freedom; $P$ =probability value

The same observations were done for the other considered characteristics. Interaction between the topography of the forest and tree stem shape was also significant $(\mathrm{P}<0.05)$. In downhill and hill side, the highest number of Isoberlinia spp. trees was recorded in the category of little developed canopy and was followed by fairly developed canopy (Figure 3a). On contrary, in the top hill, the counted numbers of trees were almost the same for fairly developed and little developed canopy (Figure 3a). As for the stem shape of trees (Figure 3b), results shown that trees were mostly straight and barely twisted. The high number of twisted trees was reported in hill side and top hill (Figure 3b). According to health statement of trees, good trees were mostly found irrespective of the topographic unit; the remaining health statements were scarce. However, rot trees were mostly reported in top hill.

\section{Discussion}

The spatial distribution and structure of tree species are often attributed to soil properties, such as water, nutrients and $\mathrm{pH}$ (Hanba, Noma, \& Umeki, 2000; Tateno \& Takeda, 2003) but also to others parameters such as climatic conditions (Hardy \& Sonké, 2004), anthropogenic pressure (Assogbadjo, Glèlè-Kakaï, Sinsin, \& Pelz, 2010) but also to dispersal agents (Hubbell, 2001; Kunz \& Lin-senmair, 2008a; 2008b). However, topography also creates a large heterogeneity in stand structure (Akpo, Grouzis, Bada,
Pontanier, \& Floret, 1999) and might affect trees growth. Relatively constant values of ecological parameters were noted on top hill, hill side and downhill. The abundance of Isoberlinia spp. trees on the hill side was due to strong root system which propagates sometimes by means of root suckers enabling high density of trees adapted to slope and stony soil condition. For the computed dendrometric parameters, $I$. doka yielded the highest values. In addition, it was on hill side that values were mostly high. This might be due to the fact that the second species i.e. $I$. tomentosa was not in his occurrence area (Akouègninou et al., 2006). Moreover, I. doka was abundant in the hill side because of his resistance to the hostility of the area and competition factors. Findings about the effect of topography on trees traits (Figure 5), revealed a significant variation. Actually, trees and topography join to create an increasingly large heterogeneity of area (Akpo et al., 1999). However, anthropogenic pressure could also be pointed out in the context of the Zouzounkan forest reserve. For instance, analysis of the possible impact of anthropogenic pressure on the dendrometric parameters of the A. leiocarpa dominated stands revealed that the overall basal area, mean height and diameter, basal area and contribution in basal area of $A$. leiocarpa presented higher values in lowpressure stands than in high-pressure stands of the species (Assogbadjo et al., 2010). 

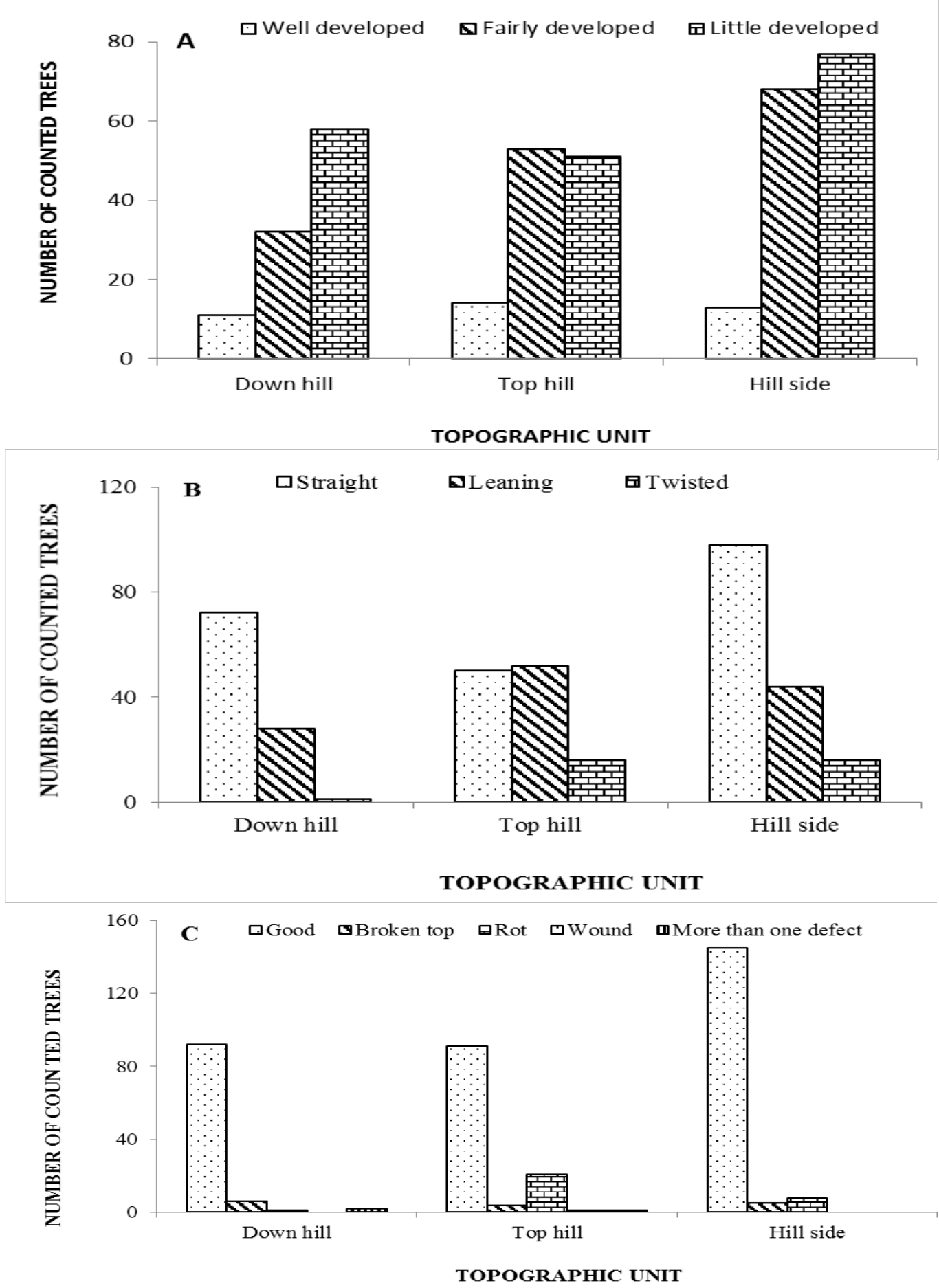

Figure 3. Number of counted Isoberlinia trees according to topographic units and trees traits: (a) crown shape, (b) stem shape, and (c) health statement of trees.

Analysis of the spatial pattern of Isoberlinia spp. revealed an aggregative distribution according to topographic units. However the aggregation degree varied with topographic units. Curves of L(r) revealed that distribution of individuals of Isoberlinia spp. was aggregative in short distance but presented sparse aggregates after large distances. This finding was consistent with studies of Kiki (2005) and Dohou (2006) in Wari-Maro forest reserve using the same spatial distribution method. The abundance of tree in hill side induced some patch with very low nearest neighbors distance. 
Dispersal mode of Isoberlinia spp. seeds which was ballochore may explained also the spatial distribution (Bationo, Ouedraogo, Somé, Pallo, \& Boussim, 2005). In fact, ripe seeds were released under mother-trees involving their concentration at short distance and thus the aggregation at short distance. The observed distribution could also be attributed to the various interactions between plant species and their environment. For Barbier, Couteron, Lejoly, Deblauwe, and Lejeune (2006), the spatial structure of plant populations in nature can be strongly affected by complex interactions (facilitation or competition) between species. The combination of the simultaneous effects of the competition and the facilitation seems to be the rule in nature; as a result, spatial structure plays a critical role in population's dynamics (Pugnaire \& Luque, 2001; Goreaud, Loreau, \& Milier, 2002). Soil conditions also determined distribution of Isoberlinia spp. Indeed, in Zouzounkan forest reserve, there is rocky outcrop. The fact that I. tomentosa prefers stony and sloping soils (Yorou, De Kesel, Sinsin, \& Codjia, 2001; Glèlè Kakaï \& Sinsin, 2009) confirms its scarcity on downhill as there is no abundance of stone in this topographic unit. In top hill and hill side, the soil is largely covered by stones, thus conditioning the presence of both Isoberlinia species. Moreover, in the Zouzounkan forest reserve, the activities of the local populations have reduced area of stable vegetation and then influenced the dynamics of distribution of the species. In fact, studies carried on the spatial structure of the species (Kelly, Bouvet, \& Picard, 2004; Djossa et al. 2008; Khatarina, Wittiga, Thiombiano, Becker, \& Hahn, 2010) shown that the spatial structure varies according to the land uses.

Aggregation distance fluctuated from one topographic unit to another. Aggregative distances found in this study (above $7 \mathrm{~m}$ ) were higher than those of Kiki (2005) and Dohou (2006) who found $6 \mathrm{~m}$ within WariMaro forest reserve. However it was on hill side that the large distance of aggregation is noted. First, it may be due to the relatively high number of individuals; second, the hill side is not favourable to logging and charcoal production due to rocky ground and difficulty to unloading. Indeed, these illegal activities were usually done by bordering people on top hill and downhill.

In Benin, no relevant conservation strategies have been defined for Isoberlinia species (Glèlè Kakaï \& Sinsin 2009). In Zouzounkan forest reserve, the same things are observed despite management policies. An effective conservation of Isoberlinia stands within Zouzounkan forest requires improvement of forest control, to avoid logging and charcoal production. Besides, in situ conservation strategies should definitely resort to plantation to permit restoration of sparse patches. Regeneration by seedling of Isoberlinia spp. was very effective for reconstitution of woodland, especially vegetative propagation capacity (Bationo et al., 2005; Dourma et al., 2006).

\section{Conclusion}

This study shown that Isoberlinia species kept its gregarious traits despite topographic units and human disturbance. Nevertheless the aggregative distance varies according to the topography. Also, ecological and dendrometric parameters and trees traits differentiated topographic units. We then accept the expressed hypotheses and we conclude that the topographical patterns of the Zouzounkan forest reserve impact treespecies distribution as well as the spatial pattern and the structure of Isoberlinia spp. However, spatial pattern which was observed in this study must be taken with caution because it might be due to human pressure. On each topographic unit especially downhill and top hill afforestation is needed within sparse aggregate. Also controls of some activities which have negative impact on the species dynamics are required. Then, awareness and improvement of local dwellers to the management of Zouzounkan forest will be crucial for effective conservation of Isoberlinia spp. trees in natural stands.

\section{Acknowledgement}

This work was support in part by West African Economic and Monetary Union (UEMOA) through the "Programme d'Appui à l'Enseignement Supérieur (PAES)" attributed to C.A. Goussanou. 


\section{References}

Agbahoungba, F. (2009). Recensement des exploitants agricoles des forêts de Zouzoukan, Fita-Agbado et Nonsina-son [Farmer's census in forests of Zouzoukan, Fita-Agbado and Nonsina-son]. Cotonou, Benin : Projet Bois de Feu Phase II, 46 p. Agresti, A. (1990). Categorical Data Analysis. John Wiley \& Sons, New York, $558 \mathrm{p}$.

Akoègninou, A., Van Der Burg, W.J., Van Der Maesen, L.J.G., Adjakidjè, V., Essou, J.P., Sinsin, B., Yèdomonhan, H. (Eds). (2006). Flore analytique du Benin [Analytical flora of Benin]. Cotonou \& Wageningen: Backuys Publishers, 1034 p.

Akpo, L.E., Grouzis, M., Bada, F., Pontanier, R., Floret, C. (2000, December). Effet du couvert sur la structure de la végétation herbacée de jachères soudaniennes [Coverage effect on herbaceous vegetation pattern of sudanian fallows]. Science et changements planétaires/Sécheresse, 10 (4), 253-261.

Assogbadjo, A.E., Glèlè Kakaï, R., Sinsin, B., Pelz, D. (2010). Structure of Anogeissus leiocarpa Guill., Perr. natural stands in relation to anthropogenic pressure within Wari-Maro Forest Reserve in Benin. African Journal of Ecology, 48 (3), 644-653. doi: 10.1111/j.1365-2028.2009.01160.x

Awokou, K.S., Ganglo, C.J., Azontondé, H.E., Adjakidjè, V., De Foucault, B. (2009). Caractéristiques structurales et écologiques des phytocénoses forestières de la forêt classée d’Itchèdè, Département du Plateau, Sud-est Bénin [Strutural and ecological charateristics of plant communities of Itchèdè forest reserve, Plateau department, South-East Benin]. Sciences and Nature, 6 (2), 125-138. http://dx.doi.org/10.4314/scinat.v6i2.4866 6.

Barbier, N., Couteron, P., Lejoly, J., Deblauwe, V., Lejeune, O. (2006). Selforganised vegetation patterning as fingerprint of climate and human impact on semiarid ecosystems. Journal of Ecology, 94 (3), 537-547. doi: 10.1111/j.1365-2745.2006.01126.x.

Bationo, B.A., Ouedraogo, S.J., Somé, A.N., Pallo, F., Boussim, I.J. (2005).
Régénération naturelle d'Isoberlinia doka Craib. et Stapf. dans la forêt classée du Nazinon (Burkina Faso) [Natural regeneration of Isoberlinia doka in Nazinon forest reserve (Burkina Faso)]. Cahiers Agricultures, 14 (3), 297-304.

Besag, J. (1977). Contribution to the discussion of Dr. Ripley's paper. Journal of Royal Statistical Society:Serie B, 39 (2), 193-195.

Clark, D.B., Clark, D.A., Read, J.M. (1998). Edaphic variation and the mesoscale distribution of tree species in a neotropical rain forest. Journal of Ecology, 86 (1), 101-112. doi: 10.1046/j.1365-2745.1998.00238.x.

Djègo, J., Gibigaye, M., Tente, B., Sinsin, B. (2012). Analyses écologique et structurale de la forêt communautaire de Kaodji au Bénin [Ecological and structural analyses of community forest of Kaodji, Benin]. International Journal of Biological and Chemical Sciences, 6 (2), 705-713. doi: http://dx.doi.org/10.4314/ijbcs.v6i2.14

Djossa, B.A., Fahr, J., Wiegand, T., Ayihouénou, B.E., Kalko, E.K., Sinsin, B. (2008). Land use impact on Vitellaria paradoxa C.F. Gaerten. stand structure and distribution patterns: a comparison of Biosphere Reserve of Pendjari in Atacora district in Benin. Agroforestry Systems, 72 (3), 205-220.

Dohou, O.R. (2006). Contribution méthodologique à l'étude de la répartition spatiale des arbres: détermination de l'aire optimale d'étude de la répartition spatiale des arbres dans un peuplement à dominance Isoberlinia spp dans la forêt classée de Wari-Maro (centre-benin), Benin [Methodological contribution to spatial distribution of trees: determination of optimal area for tree's spatial distribution study in tree stands dominated by Isoberlina spp in WariMaro forest reserve]. Dissertationn thesis, Faculté des Sciences Agronomiques, Université d'Abomey Calavi, Benin, 93p.

Dourma, M., Guelly, K.A., Kokou, K., Batawila, K., Wala, K., Bellefontaine, R., Akpagana., K. (2006). Multiplication par drageonnage d'Isoberlinia doka et $I$. tomentosa au sein des formations arborées du Nord-Togo [Propagation of Isoberlinia 
doka and I. tomentosa by suckering in tree formations in northern Togo]. Bois et Forêts des Tropiques, 289 (3), 49-57.

Fandohan, A.B., Assogbadjo, A.E., Glèlè Kakaï, R., Sinsin, B., Van Damme, P. (2010). Impact of habitat type on the conservation status of tamarind (Tamarindus indica L.) populations in the W National Park of Benin. Fruits, 65, 1119. doi: 10.1051/fruits/2009037.

Glèlè Kakaï, R., Sinsin, B. (2009). Structural description of two Isoberlinia dominated communities in the Wari-Maro forest reserve (Benin). South African Journal of Botany, 75 (1), 43-51. https://doi.org/10.1016/j.sajb.2008.07.003

Goreaud, F., Loreau, M., Millier, C. (2002). Spatial structure and the survival of an inferior competitor: a theoretical model of neighborhood competition in plants. Ecological Modelling, 158 (1-2), 1-19. https://doi.org/10.1016/S03043800(02)00058-3.

Goreaud, R., Courbaud, B., Collinet, F. (1999). Spatial structure analysis applied to modeling of forest dynamics: a few examples. In: A. Amaro, A. and M. Tomé (Eds), Proceedings of the IUFRO Workshop, Empirical and process based models for forest tree and stand growth simulation (155-172). Novas Tecnologias, Oerias, PT.

Guédou, R. (2005). Impacts de la production du bois énergie et du charbon de bois sur les peuplements à Anogeissus leiocarpa (DC) Guill et Perr. dans la forêt classée de l'Ouémé-Boukou [Impacts of fuelwoods and charcoal production on Anogeissus leiocarpa stands in Oueme-Boukou forest reserve]. Master dissertation, Faculté des Sciences Agronomiques, Université d'Abomey Calavi, Benin.

Hanba, Y.T., Noma, N., Umeki, K. (2000). Relationship between leaf characteristics, tree sizes and species distribution along a slope in a warm temperate forest. Ecological Research, 15 (4), 393-403.

Hardy, O.J., Sonké, B. (2004). Spatial pattern analysis of species distribution in a tropical rain forest of Cameroon: assessing the role of limited dispersal and niche differentiation. Forest Ecology and Management, 197 (1-3), 191-202. https://doi.org/10.1016/j.foreco.2004.05.0 14.

Hubbell, S.P. (2001). The unified neutral theory of biodiversity and biogeography. Princeton University Press, 448 p.

Jones, M.M., Tuomisto, H., Borcard, D., Legendre, P., Clark, D.B., Olivas, P.C. (2008). Explaining variation in tropical plant community composition: influence of environmental and spatial data quality. Oecologia, 155 (3), 593-604.

Kelly, B.A., Bouvet, J-M., Picard, N. (2004). Size class distribution and spatial pattern of Vitellaria paradoxa in relation to farmers' practices in Mali. Agroforestry Systems, 60 (1), 3-11.

Khatarina, S., Wittiga, R., Thiombiano, A., Becker, U., Hahn, K. (2010). Impact of land-use type and bark and leafharvesting on population structure and fruit production of the baobab tree (Adansonia digitata L.) in a semi-arid savanna, West Africa. Forest Ecology and Management, 260 (11), 2035-2044. https://doi.org/10.1016/j.foreco.2010.09.0 09

Kiki, J.M. (2005). Etude de la répartition spatiale des arbres de Isoberlinia spp. dans la forêt classée de Wari-Maro (Centre Benin) [Study of spatial distribution of Isoberlinia spp. Trees in Wari-Maro forest]. Thesis dissertation, Faculté des Sciences Agronomiques, Université d'Abomey Calavi, Benin, 101p.

Klimas, C.A., Kainer, K.A., Wadt, L.H.O. (2007). Population structure of Carapa guianensis in two forest types in the southwestern Brazilian Amazon. Forest Ecology and Management, 250 (3), 256265. https://doi.org/10.1016/j.foreco.2007.05.0 25

Kunz, B.K., Linsenmair, K.E. (2008a). Seed size selection by olive baboons. Primates, 49 (4), 239-245.

Kunz, B.K., Linsenmair, K.E. (2008b). The role of the olive baboon (Papio anubis, Cercopithecidae) as seed disperser in a savanna forest mosaic of West Africa. Journal of Tropical Ecology, 24 (3), 235246. 
https://doi.org/10.1017/S02664674080050 14.

Lan, G., Hu, Y., Cao, M., Zhu, H. (2011). Topography related spatial distribution of dominant tree species in a tropical seasonal rain forest in China. Forest Ecology and Management, 262 (8), 15071513.

https://doi.org/10.1016/j.foreco.2011.06.0 52.

Law, R., Illian, J., Burslem, D.F.R.P., Gratzer, G., Gunatilleke, C.V.S., Gunatilleke, I.A.U.N. (2009). Ecological information from spatial patterns of plants: insights from point process theory. Journal of Ecology, 97 (4), 616-628. doi: 10.1111/j.1365-2745.2009.01510.x.

Lejeune, P. (2001). Arpent 2.0, logiciel de saisie de données d'arpentage - Guide d'utilisation [Arpent 2.0, surveying data aquisition software]. FUSAGx. Note Technique Forestière, 5, 1-12.

Liang, S-C., Dong, M. (2004). Spatial heterogeneity of population structure of the mangrove Bruguiera gymnorrhiza at Yingluo Bay, South-China Coast. Acta Botanica Sinica, 46 (9), 1015-1024.

Liebhold, A.M., Gurevitch, J. (2002). Integrating the statistical analysis of spatial data in ecology. Ecography, 25 (5), 553-557. doi: 10.1034/j.16000587.2002.250505.x.

Linares-Palomino, R. (2005). Spatial distribution patterns of trees in a seasonally dry forest in the Cerros de Amotape National Park, northwestern Peru. Revista Peruana de Biologia, 12 (2), 317-326. http://dx.doi.org/10.15381/rpb.v12i2.2405. Lomolino, M.V., Sax, D.F., Brown, J.H.. (2004). Foundations of biogeography. Chicago: Chicago University Press, 1291 p.

Oliveira-Filho, A.T., Vilela, E.A., Carvalho, D.A., Gavilanes, M.L. (1994). Effects of soils and topography on the distribution of tree species in a tropical riverine forest in south-eastern Brazil. Journal of Tropical Ecology, $10 \quad$ (4), 483-508. https://doi.org/10.1017/S02664674000081 78

Orthmann, B. (2005). Vegetation ecology of a woodland-savanna mosaic in central
Benin (West Africa): Ecosystem analysis with a focus on the impact of selective logging. PhD dissertation, Rostock, 139 p. Phillips, O.L., Vargas, P.N., Monteagudo, A.L., Cruz, A.P., Zans, M.E.C., Sanchez, W.G., Yli-Halla, M., Rose, S. (2003). Habitat association among Amazonian tree species: a landscape scale approach. Journal of Ecology, 91 (5), 757-775. doi : 10.1046/j.1365-2745.2003.00815.x

PBF-II (Projet Bois de Feu II) (2010). Plan d'aménagement et de gestion simplifiée de la forêt intercommunale de Zouzoukan [Simplified management plan of Zouzoukan forest reserve]. MEPN/DGFRN, Cotonou, Benin, 97 p.

Pugnaire, F.I., Luque, M.T. (2001). Changes in plant interactions along a gradient of environmental stress. Oikos, 93 (1), 4249 doi: 10.1034/j.16000706.2001.930104.x.

Revilla, E., Palomares, F. (2002). Spatial organization, group living and ecological correlates in low-density populations of Eurasian badgers, Meles meles. Journal of Animal Ecology, 71 (3), 497-512. doi: 10.1046/j.1365-2656.2002.00617.x

Ripley, B.D. (1981). Spatial statistics. New York, USA: Wiley, $272 \mathrm{p}$.

Ripley, B. (1977). Modeling spatial patterns. Journal of the Royal Statistical Society: Series B, 39 (2), 172-212.

Rushton, S.P., Ormerod, S.J., Kerby, G. (2004). New paradigms for modeling species distributions. Journal of Applied Ecology, 41 (2), 193-200. doi: 10.1111/j.0021-8901.2004.00903.x

Schemske, D.W. (2002). Ecological and evolutionary perspectives on the origins of tropical diversity. In: R., Chazdon, and T. Whitmore (Eds), Foundations of tropical forest biology (163-173), Classic papers with commentaries, Chicago, IL: Univ. Chicago Press.

Slansky, M. (1962). Contribution à l'étude des sols sédimentaires côtiers du Dahomey et du Togo [Contribution to study of sedimentary coastal soil]. Mémoire de Bureau de Recherches Géologiques Minières, 270 p.

Svenning, J-C., Kinner, D.A., Stallard, R.F., Engelbrecht, B.M.J., Wright, S.J. (2004). Ecological determinism in plant 
community structure across a tropical forest landscape. Ecology, 85 (9), 25262538. doi: 10.1890/03-0396.

Tateno R., Takeda, H. (2003). Forest structure and tree species distribution in relation to topography-mediated heterogeneity of soil nitrogen and light at the forest floor. Ecological research, 18 (5), 559-571.

Valencia, R., Foster, R.B., Villa, G., Condit, R., Svenning, J.C., Hernández, C., Romoleroux, K., Losos, E., Magård, E., Balslev, H. (2004). Tree species distributions and local habitat variation in the Amazon: a large forest plot in eastern Ecuador. Journal of Ecology, 92 (2), 214$229 . \quad$ doi: $10.1111 /$ j.00220477.2004.00876.x.

Wiegand, T., Moloney, K.A. (2004). Rings, circles, and null models for point pattern analysis in ecology. Oikos, 104 (2), 209$229 . \quad$ doi: 10.1111/j.00301299.2004.12497.x.

White, F. (1983). The vegetation map of Africa south of the Sahara, 2nd ed. Paris, UNESCO, $356 \mathrm{p}$.

Yorou, N.S., De Kesel, A., Sinsin, B., Codjia, J-C. (2001). Biodiversité et productivité des champignons comestibles de la forêt classée de Wari-Maro (Bénin). Systematics and Geography of Plants, 71 (2), 613-625. doi: 10.2307/3668706. 